\title{
"Level of usage of income smoothing as a creative accounting tool by Balkan banks"
}

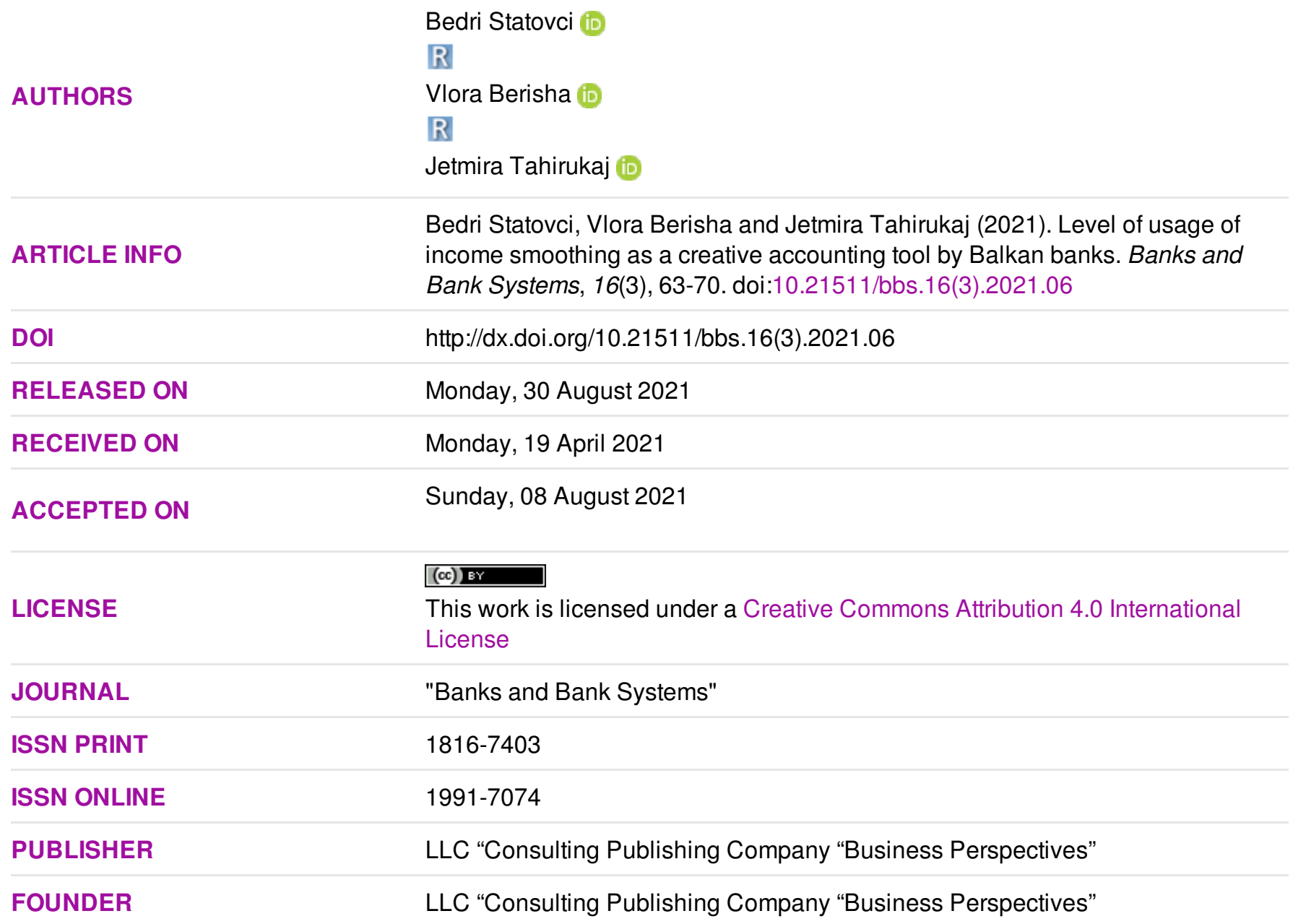

NUMBER OF REFERENCES

34

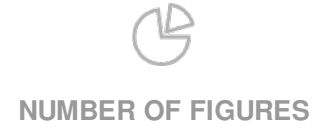

1
NUMBER OF TABLES

3

(C) The author(s) 2021. This publication is an open access article. 


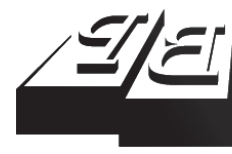

\section{BUSINESS PERSPECTIVES}

LLC "CPC "Business Perspectives" Hryhorii Skovoroda lane, 10, Sumy, 40022, Ukraine www.businessperspectives.org
Received on: $19^{\text {th }}$ of April, 2021 Accepted on: $8^{\text {th }}$ of August, 2021 Published on: $30^{\text {th }}$ of August, 2021

(c) Bedri Statovci, Vlora Berisha, Jetmira Tahirukaj, 2021

Bedri Statovci, Dr., Business Faculty, University Haxhi Zeka, Kosovo.

Vlora Berisha, Ph.D., Professor, Business Faculty, Accounting and Finance Department, University Haxhi Zeka, Kosovo. (Corresponding author)

Jetmira Tahirukaj, MSc (c) Faculty, Accounting and Finance Department, University Haxhi Zeka, Kosovo.

\section{LEVEL OF USAGE OF INCOME SMOOTHING AS A CREATIVE ACCOUNTING TOOL BY BALKAN BANKS}

\begin{abstract}
The main objective of this study is to find out if Balkan banks use income smoothing (IS) as a creative accounting practice. The IS level is analyzed to see whether banks are focused on these practices as a tool to produce a better picture of financial views in the sight of decision makers. The data are provided from the audited financial reports presented on the banks' web pages. Eckel's modified equation was used to find out if banks use the technique of IS. As a result, the findings showed that banks use IS, and the factors that influence the use of this practice are analyzed. The factors studied are: age of banks, profitability, and loan provision. Of a total of seven banks in Kosovo, only three use income smoothing. In Albania, of a total of 11 banks, only one uses income smoothing. Surprisingly, the results show that none of the variables measured affect the usage of income smoothing. The study contributes to understanding the practice of IS on the one hand, and on the other hand, to opening the eyes of investors and depositors promoting vigilance when they make decisions about investing their funds in banks.
\end{abstract}

Keywords

accounting, banking industry, number games, income smoothing

JEL Classification $\quad$ M41, G21, M49

\section{INTRODUCTION}

The main goal, not only for banks, but for all institutions is to increase revenues and profits. Increasing revenue is an important aim for the company to look decently in the eyes of investors so that they can make easier for them to entrust their funds to these companies. From the investor's premise: Investors invest their capital when a company has little fluctuations in their profits and incomes (Balli et al., 2020; B.-H. Bao, \& D.-H. Bao, 2004). Managers often use policies such as income smoothing to achieve this premise (Warner et al., 2003). Income smoothing is defined as "A shape of earnings management constructed to mitigate peaks and valleys from a normal earnings series, including steps to mitigate and "store" profits during good years for use during slower years" (Mulford \& Comiskey, 2002, p. 3). SEC Director, Arthur Levitts called the "number game" all practices that seek to take advantage of the gap left by accounting principles. The scandals of the last two decades of large and world-renowned companies have turned their attention to the study of factors influencing accounting manipulations. These manipulations by different companies, which are involved in fraudulent practices, have been replaced by different names as creative accounting. Often many researchers (Mulford \& Comiskey, 2002; Ozili, 2019) have described creative accounting as an instrument to mislead investors by showing them high net profits. As mentioned above, IAS allow some degree of flexibility and interpretation. It is up to the company and its 
management if they choose to be in line with these principles, or to extend them, but these still can be called mistakes but not fraud, as long as they are within the framework of the rules, albeit in their limit. If companies act in violation of what the IAS say is called fraud, if it acts in accordance with them but exploits the gaps in the IAS, then this behavior is called as a creative accounting. Creative accounting can be described as a method in which accountants use vent in IAS to present financial success in a one-sided way (Atik, 2009; Motley, 2002; Largay, 2002; Mulford \& Comiskey, 2002). The fierce competition of the 21st century and globalization can be considered as an indicator that pushes organizations to use creative accounting, in particular income smoothing. Banks use creative accounting: just to look better than they are; to show that they have better results compared to competitors; and to attract investors' decisions to invest their funds in their banks. As a consequence, the main objective of this study is to explore if banking organizations in two Balkan countries, Kosovo and Albania, use income smoothing as a creative technique to help banks better present their financial health to different audiences.

\section{LITERATURE REVIEW}

By reviewing the accounting literature (Al-Taie et al., 2017; Amat \& Gowthorpe, 2004; Motley, 2002; Balaciu \& Pop, 2008; Li \& Richie, 2016; Liberto, 2019; Mulford \& Comiskey, 2002; Shah \& Butt, 2011), one can say that a type of so-called creative accounting policy is income smoothing. Income smoothing as a practice has been favored topic for many accounting and finance scholars for many years. Schipper (1989) defines smoothing "as a deliberate interference with the external financial reporting process, with the intent to obtain certain personal benefits" (Schipper, 1989, p. 91). Barnea et al. (1976, p. 110) also give a definition about smoothing: "smoothing is practiced in order to affect the income stream presumably utilized by financial statements users, the focus is exclusively on the net income numbers (after extraordinary items), when, in fact, ordinary income (before extraordinary items) per share is the focal number of users of financial statements and, therefore, should be the object of smoothing." B.-H. Bao and D.-H. Bao (2004) describe income smoothing as an action taken by managers to boost profits when incomes are low and to reduce profits when incomes are high. According to Mulford and Comiskey (2002), income smoothing is a form of profit manipulation created to detach "peaks and gully" from a standard sequence of profits, incorporating actions to shrink and "maintain" profits over good years for use during moderate years. Process of doing accounting creative in a company, according to many scholars (Balaciu \& Pop, 2008; Effiok \& Okon, 2012; Florin-Constantin, 2012; Yaseen et al., 2018), involves manipulating financial numbers to arrive at an answer that meets the com- pany's management needs, rather than providing objective information to external recipients mainly shareholders. One point to emphasize at this early stage is that creative accounting, like everything, will never be completely erased. If a company's management is destined to deceive its auditors and shareholders, it is likely to achieve it, at least in the short term (Warner et al., 2003). Li and Richie (2016) studied the effect of IS on the debt market. The results of the study found that firms with excessive income smoothing rankings show lower debt costs, denoting that the effect of information signals on revenue mitigation predominates with ambiguous information. The results showed that the impact of IS on reducing the cost of debt is stronger in organizations with more ambiguous information and greater risk of anxiety. Salih et al. (2020) present their results by showing that tax expenditures depict the most important factor influencing the decision of the administration of Sudanese banks to pursue the IS policy, followed by the management incentives factor, the bonus plan and the ownership form. The results of the study by Sparta and Trinova (2020) showed that income smoothing positively affect banks' credit defacement losses. Takasu (2012) found that the income smoothing by bank management reduces the cost of bank loans. Ozili (2019) has found that banks use loan loss provisions to smooth positive (non-negative) incomes especially during the post-2008 crisis period, and this behavior is diminished by strong investor protection. It has also been found that banks in a highly corrupt environment smooth their positive (non-negative) incomes compared to smoothing profit distribution. Fonseca and González (2008) showed that the smoothing of 
the bank's income rely on investor safe keeping, regulation and supervision, disclosure, financial structure and financial development. Alexandri and Anjani (2014) found that important factors that affect income smoothing are bank size, profitability and financial leverage. Abogun et al. (2021) showed that IS have an important non-positive impact on the firm's value. The findings also emphasized that market risk is an important variable that determines the relationship between IS and firm worth. Goel's (2016) analytical results on forecast income smoothing and investment opportunities show that job protection concerns provide managers with an incentive to mitigate profits, given current and future performance. Also, the research found that the rate of IS is negatively correlated with the level of investment opportunities in current low/high performance periods in the future and positively correlated with the level of investment opportunities in current high/low performance periods in the future. Riahi-Belkaoui (2003) found that income smoothing varies depending on managers' job security concerns, as indicated by a certain level of investment opportunities for growth opportunities. Ergin (2011) showed that $82 \%$ of organizations listed on the Istanbul Stock Exchange from 2006 to 2010 use IS practice. The results showed that of these $82 \%$ of firms that use income smoothing, $30 \%$ are manufacturing companies, $21 \%$ financial institutions, and $36 \%$ belong to the service industry. Abu-Serdaneh (2018) founded no conclusive evidence that Jordanian banks used provisions to smooth incomes and manage the capital ratio. The three most popular incentives for managers to apply income smoothing are:

1) to reduce the strong risk grasp by investors;

2) better trading conditions with customers and suppliers; and

3) future growth prospects to investors (Graham et al., 2005).

Effiok and Okon (2012) evaluated the effect of creative accounting on management decisions of selected companies listed on the Nigeria Stock Exchangea and concluded that financial statement manipulation has a significant impact on the performance of stock decisions and firm management in relation to their shares. The aim is to pay less taxes and less dividends and, accordingly, "create" financial statements. This practice can lead to tax evasion and loss of money by investors.

Mulford and Comiskey (2002) provide three ways in which income smoothing is used in the income statement, they are:

1. "Moving the items of the income statement either within or outside the operating income".

2. "By moving costs from sales costs to categories of general or administrative sales expenses, from this action an increase in gross profit will be produced".

3. "By moving operations out of operations classified as discontinued when they are sold at a profit and in discontinued operations when they are sold at a loss, a higher level of revenue is generated from continuing operations".

\section{METHODOLOGY}

\subsection{Income variability approach}

According to this theory, there is a central premise that whenever income fluctuations are reduced by a smoothing variable or based on an expected pattern, one can conclude that revenues have smoothed (Mostafa \& Hossein, 2013).

Eckel's model resents income smoothing through the following equation:

This method was also used in previous studies (Albrecht \& Richardson, 1990; Habib, 2005) to determine the presence of income smoothing. To conduct the analysis of income smoothing in commercial banks in Kosovo and Albania, secondary quantitative data are used such as commercial banks' financial statements published on their official websites. This research includes a period of 2005-2018.

Kosovo has a banking system of 10 banks, where two are with local capital and eight with foreign capital. Albania has a banking system of a total of 


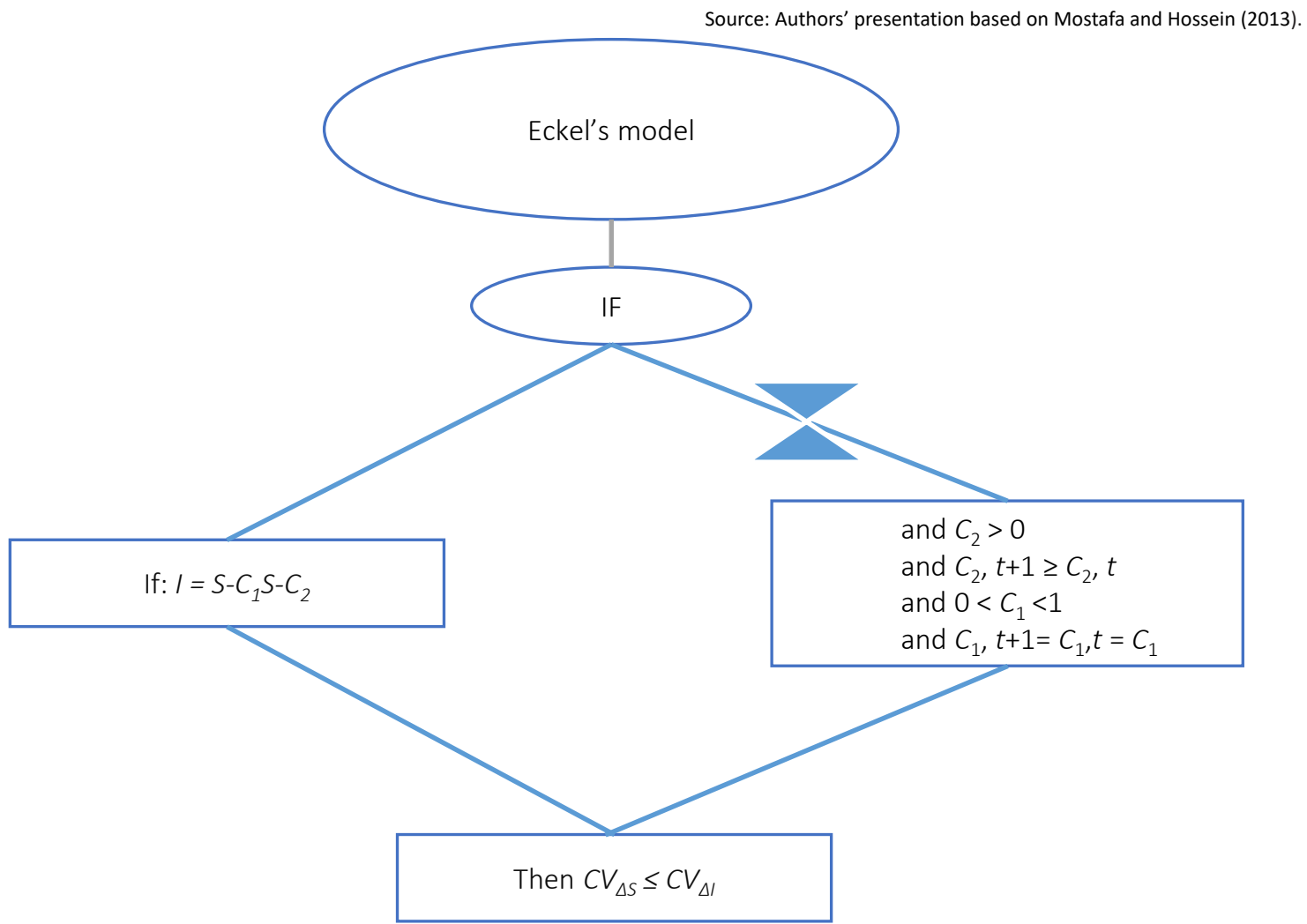

Note: $I$ - Income; $S$ - Income from sales; $C_{2}$ - Fixed costs; $C_{l}$ - The rate of variable costs in sales expressed; $C V_{\Delta s}-$ Coefficient of variation for changes in sales; $C V_{\Delta I}$ - Coefficient of variation for change in income.

Figure 1. Eckel's model

12 banks. This study has included 11 banks to make a comparative analysis with banks in Kosovo.

The model used in this study is presented below:

$$
\begin{aligned}
& Y t_{\text {(income smoothing })}=b_{0}+b_{1} X_{1(\text { Size of banks })}+ \\
& +b_{2} X_{2(\text { age of banks) }}+b_{3} X_{3(\text { profitability })}+ \\
& b_{4} X_{4(\text { loan provision })}+b_{4} X_{5 \text { (Debt financing })}+e .
\end{aligned}
$$

This model is composed of a total of six variables, that is, one dependent variable and five independent variables. The dependent variable is income smoothing, while the independent ones are bank size, age of banks, profitability, loan provision and debt financing.

Some brief explanations of these variables will be given later in the study to provide a clear definition about each variable and their importance.

Income smoothing - The importance of studying income smoothing is to discover if banks in
Kosovo and Albania smooth revenues by reducing profits.

Size of banks - Previous research reveal that firm size affects income smoothing behavior, so this paper will analyze this. Habib (2005) finds that small enterprises fix income significantly more than big enterprises.

Age of banks - Many researchers believe that most of the new companies (banks) involved may have the most fluctuations or changes in income. This is because they are not yet mature and have less experience in their activities (Trisanti, 2014).

Profitability - Previous studies have concluded that most companies (banks) smooth their income when their profitability is relatively low. Atik (2009) suggests that companies (banks) with declining profits tend to adjust their earnings.

1 According to Trisanti (2014), this econometric model is the right choice. 
Credit provision - loan loss provisions are an estimate of the potential losses that a bank may incur due to credit risk. Provisions for loan losses are treated as an expense in the financial statements for debt.

Table 1. Information about variables

\begin{tabular}{|c|c|}
\hline Variables & Description \\
\hline$Y t$-Income smoothing & Eckel's model fitted for this study \\
\hline$X_{1}$ - Size of banks & Total employees \\
\hline$X_{2}$ - Age of banks & Age of banks \\
\hline$X_{3}$ - Profitability & $\begin{array}{l}\text { Return on assets - the ratio between } \\
\text { net profit and total assets } \\
\text { ROA = net profit/total assets }\end{array}$ \\
\hline$X_{4}-$ Loan provision & $\begin{array}{l}\text { Loan provision according to financial } \\
\text { statement }\end{array}$ \\
\hline$e$-error term & $\begin{array}{l}\text { All variables not included in the model, } \\
\text { but which may affect revenue mitigation }\end{array}$ \\
\hline
\end{tabular}

\section{ANALYSIS AND RESULTS}

To analyze whether banks in Kosovo and Albania are practicing income smoothing, the income smoothing index formula was used, which was first developed by Al-Taie et al. (2017). This IS formula has been modified from original Eckel's model.

Income smoothing index:

$$
C V I s=\frac{C V i}{C V S},
$$

where

$$
\begin{gathered}
C V i=\frac{\sigma \Delta \text { income }}{\mu \Delta \text { income }}, \\
C V S=\frac{\sigma \Delta \text { the revenue }}{\mu \Delta \text { the revenue }},
\end{gathered}
$$

Explanation: $C V i=$ standard deviation of change in gross profit/average gross profit; $C V s=$ standard deviation of changes in service revenues/average service revenues.

If $\mathrm{CVi}$ (coefficient of variation for income) is less than $C V s$ (coefficient of variation in revenue from the service), the ratio $C V I s=(C V i / C V s)$ will be less than one, and if this smoothing ratio revenue is less than one, it is suggested that the bank is performing income smoothing.
Based on this formula, the number of banks using income smoothing in Kosovo and Albania is presented in Table 2.

Table 2. Number of banks in Kosovo and Albania that apply and do not apply income smoothing

\begin{tabular}{|c|c|c|c|c|}
\hline & Pair & $\mathbf{N}$ & $\begin{array}{c}\text { Beta } \\
\text { coefficient }\end{array}$ & P-value \\
\hline Pair 1 & $\begin{array}{l}\text { Income smoothing \& } \\
\text { Bank size }\end{array}$ & 4 & 0.457 & 0.543 \\
\hline Pair 2 & $\begin{array}{l}\text { Income smoothing \& } \\
\text { Age of banks }\end{array}$ & 4 & 0.404 & 0.596 \\
\hline Pair 3 & $\begin{array}{l}\text { Income smoothing \& } \\
\text { Profitability }\end{array}$ & 4 & 0.907 & 0.093 \\
\hline Pair 4 & $\begin{array}{l}\text { Income smoothing \& } \\
\text { Credit provision }\end{array}$ & 4 & -0.771 & 0.229 \\
\hline Pair 5 & $\begin{array}{l}\text { Income smoothing \& } \\
\text { Debt financing }\end{array}$ & 4 & 0.603 & 0.397 \\
\hline
\end{tabular}

\begin{tabular}{l|c:c}
\multicolumn{1}{c}{ Banks } & \begin{tabular}{c} 
Source: Authors' analysis. \\
\multicolumn{1}{c}{ Banks in } \\
Kosovo
\end{tabular} & $\begin{array}{l}\text { Banks in } \\
\text { Albania }\end{array}$ \\
\hline $\begin{array}{l}\text { Banks that do not apply } \\
\text { income smoothing }\end{array}$ & 4 & 10 \\
\hdashline $\begin{array}{l}\text { Banks that apply income } \\
\text { smoothing }\end{array}$ & 3 & 1 \\
\hline Total & 7 & 11 \\
\hline
\end{tabular}

Table 3. Empirical model

Based on the results of this study, there is a positive linear relationship between the size of banks and income smoothing, if the size of banks increases by $1 \%$, keeping constant other factors, the income smoothing will increase by $0.457 \%$. Such a correlative link is argued by the fact that commercial banks in recent years have been quite stable in their size and have not affected the increase in income smoothing. Also, if the age of banks increases by $1 \%$, the income smoothing will increase by $0.404 \%$, there is no effect on the income smoothing as the value of the age of banks is greater than the level of $5 \%$, P-value $(0.404>0.05)$. So, this positive linear relationship is characteristic of both types of commercial banks, those with domestic capital, but also those with foreign capital. A positive linear relationship between bank profitability and income smoothing is found; if profitability increases by $1 \%$, while keeping other factors constant, income smoothing will increase by $0.907 \%$, there is no effect on the income smoothing, since the statistical level of $5 \%$ is greater, $\mathrm{P}$-value $(0.907$ $>0.05)$. Such a correlative link is argued by the 
fact that commercial banks in recent years have been quite profitable and this profit has not affected the IS. In general, the banking sector in Kosovo is considered a very profitable sector, with an efficient management of financial risks and high liquidity. The coefficient of the loan provision variable is negative (see Table 3 ), so there is a negative relationship between the dependent variable (income smoothing) and independent variables (loan provision). Significance value is not within the level of statistical significance $\mathrm{P}$-value $=5 \%$. A $1 \%$ increase in loan provision will affect the reduction of income smoothing by $-0.771 \%$. The empirical results of this study show there is a positive linear relationship between the debt financing ratio and income smoothing of commercial banks. If debt financing increases by $1 \%$, while keeping other factors constant, income smoothing will increase by 0.397 ; this result is inaccurate with the significance level of $5 \%$, P-value (0.397 > 005). Based on these results, it can be said that this paper does not find a statistical significance in the analysis of these variables. Although there are four banks that use this technique, none of the factors analyzed affect its use.

\section{CONCLUSION}

Some practitioners and scholars consider creative accounting illegal. Others, however, think that it involves gaining flexibility in accounting standards, and take it as a legal action. This study attempted to show if banks in the two Balkan countries use income smoothing practices and examine if the factors reviewed in the literature affect application of the income smoothing technique. There are four banks that use creative accounting through income smoothing (three banks in Kosovo and just one in Albania). Being creative in accounting distorts a true and objective view of the financial position of companies, although it is argued that it is perfectly legitimate. Having analyzed factors such as bank size, bank age, profitability, loan provision and debt financing, it was found to be irrelevant for income smoothing. The results obtained are opposite to the research work of Trisanti in the year 2014 because these variables affect creative accounting practices in developed countries. Recommendations for banks in Kosovo and Albania that use income smoothing practices are to be careful when applying income smoothing, as it can have negative consequences for business, because it can deceive the judgment of investors and individuals interested in the bank's financial information. Auditors are also encouraged to attend more continuing professional development courses so that they can better understand when an organization is engaged in an income smoothing practice and find ways to prevent this practice from escalating into financial fraud.

\section{AUTHOR CONTRIBUTIONS}

Conceptualization: Vlora Berisha.

Data curation: Vlora Berisha.

Formal analysis: Jetmira Tahirukaj.

Funding acquisition: Bedri Statovci.

Investigation: Jetmira Tahirukaj.

Methodology: Bedri Statovci.

Project administration: Vlora Berisha.

Software: Jetmira Tahirukaj.

Supervision: Vlora Berisha.

Validation: Jetmira Tahirukaj.

Visualization: Bedri Statovci.

Writing - original draft: Vlora Berisha.

Writing - review \& editing: Bedri Statovci. 


\section{REFERENCES}

1. Abogun, S., Adigbole, E. A., \& Olorede, T. E. (2021). Income smoothing and firm value in a regulated market: the moderating effect of market risk. Asian Journal of Accounting Research, aheadof-print. https://doi.org/10.1108/ AJAR-08-2020-0072

2. Abu-Serdaneh, J. (2018). Bank loan-loss accounts, income smoothing, capital management, signaling and procyclicality. Journal of Financial Reporting and Accounting, 16(4), 677-693. https:// doi.org/10.1108/JFRA-06-20160041

3. Albrecht, W. D., \& Richardson, F. M. (1990). Income Smoothing by Economy Sector. Journal of Business Finance \& Accounting, 17(5), 713-730. https://doi. org/10.1111/j.1468-5957.1990 tb00569.x

4. Alexandri, M. B., \& Anjani, W. K. (2014). Income smoothing: impact factors, evidence in Indonesia. International Journal of Small Business and Entrepreneurship Research, 3(1), 21-27. Retrieved from https://www.eajournals.org/ wp-content/uploads/IncomeSmoothing-Impact-Factors-Evidence-In-Indonesia1.pdf

5. Al-Taie, B. F. K., Flayyih, H. H., \& Talab, H. R. (2017). Measurement of income smoothing and its effect on accounting conservatism: An empirical study of listed companies in the Iraqi stock exchange. International Journal of Economic Perspectives, 11(3), 710-719.

6. Amat, O., \& Gowthorpe, C. (2004). Creative Accounting: Nature, Incidence and Ethical Issues. SSRN Electronic Journal, 1-19. https://doi.org/10.2139/ ssrn. 563364

7. Atik, A. (2009). Detecting income-smoothing behaviors of Turkish listed companies through empirical tests using discretionary accounting changes. Critical Perspectives on Accounting, 20(5), 591-613. https://doi.org/10.1016/j. сра.2008.01.003
8. Balaciu, D., \& Pop, C. M. (2008). Is creative accounting a form of manipulation? Annals of the University of Oradea, Economic Science Series, 17(3), 936-941. Retrieved from https://citeseerx. ist.psu.edu/viewdoc/download?d oi=10.1.1.599.422\&rep=rep1\&ty pe $=$ pdf

9. Balli, F., De Bruin, A., Balli, H. O., \& Karimov, J. (2020). Corporate net income and payout smoothing under Shariah compliance. Pacific-Basin Finance Journal, 60, 101265. https://doi.org/10.1016/j. pacfin. 2020.101265

10. Bao, B.-H., \& Bao, D.-H. (2004). Income Smoothing, Earnings Quality and Firm Valuation. Journal of Business Finance \& Accounting, 31(9-10), 1525-1557. https://doi.org/10.1111/j.0306686X.2004.00583.X

11. Barnea, A., Ronen, J., \& Sadan, S. (1976). Classificatory Smoothing of Income with Extraordinary Items: Research Implications. Accounting Review, 52(2), 516-524. Retrieved from https://www.jstor. org/stable/245430

12. Effiok, O. S., \& Okon, E. E. (2012). Creative Accounting and Managerial Decision on Selected Financial Institutions in Nigeria. International Journal of Business Research and Management (IJBRM), 3(1), 35-47. Retrieved from https://www.cscjournals.org/ manuscript/Journals/IJBRM/Volume3/Issue1/IJBRM-61.pdf

13. Ergin, E. (2010). Income Smoothing: Evidence from Turkey. Retrieved from https:// arastirmax.com/tr/system/files/ dergiler/31198/makaleler/1/2/ arastirmax-karin-istikrarli-halegetirilmesi-turkiye-ornegi.pdf

14. Florin-Constantin, D. (2017). Creative Accounting Through the Policies and Accounting Options. Anale. Seria Stiinte Economice. Timisoara, XVIII, 180-185. Retrieved from https://econpapers. repec.org/article/tdtannals/v_3axv iii_2fsupplement_3ay_3a2012_3ap _3a180-184.htm
15. Fonseca, A. R., \& González, F. (2008). Cross-country determinants of bank income smoothing by managing loan-loss provisions. Journal of Banking \& Finance, 32(2), 217-228. https://doi.org/10.1016/j.jbankfin.2007.02.012

16. Goel, S. (2016). Investment opportunity and anticipatory smoothing in corporate enterprises in India. Journal of Financial Crime, 23(3), 655-670. https://doi.org/10.1108/JFC-092015-0048

17. Graham, J. R., Harvey, C. R., \& Rajgopal, S. (2005). The economic implications of corporate financial reporting. Journal of Accounting and Economics, 40(1-3), 3-73. https://doi.org/10.1016/j.jacceco.2005.01.002

18. Habib, A. (2005). Firm-Specific Determinants of Income Smoothing in Bangladesh: An Empirical Evaluation. Advances in International Accounting, 18, 53 71. https://doi.org/10.1016/S08973660(05)18003-9

19. Largay, J. A. (2002). Lessons from Enron. Accounting Horizons, 16(2), 153-156. https://doi.org/10.2308/ acch.2002.16.2.153

20. Li, S., \& Richie, N. (2016). Income smoothing and the cost of debt. China Journal of Accounting Research, 9(3), 175-190. https:// doi.org/10.1016/j.cjar.2016.03.001

21. Liberto, D. (2019). Creative Accounting Definition. Investopedia. Retrieved from https://www.investopedia.com/ terms/c/creative-accounting.asp

22. Mostafa, M. Z., \& Hossein, R. (2013). Standards of investments, income smoothing of central and peripheral industries. Journal of American Science, 9(3s), 9-18. Retrieved from http://www.jofamericanscience.org/journals/am-sci/ am0903s/002_16694am0903s_9_18. pdf

23. Motley, L. B. (2002). Lessons from Enron. (Customer Satisfaction). ABA Bank Marketing. Retrieved from https://www.thefreelibrary. 
com/Lessons+from+Enron.+(Cust omer+Satisfaction).-a089025162

24. Mulford, W. C., \& Comiskey, E. E. (2002). The Financial Numbers Game: Detecting Creative Accounting Practices. Harvard Business Review. Retrieved from https://nacm.org/pdfs/gscfm/FW_ TheFinancialsNumbersGame.pdf

25. Ozili, P. K. (2019). Bank income smoothing, institutions and corruption. Research in International Business and Finance, 49, 82-99. https://doi.org/10.1016/j. ribaf.2019.02.009

26. Riahi-Belkaoui, A. (2003). Anticipatory Income Smoothing and the Investment Opportunity Set: An Empirical Test of the Fudenberg and Tirole (1995) Model. Review of Accounting and Finance, 2(2), 99-117. https://doi. org/10.1108/eb027009

27. Salih, K., Abdalla, S., Gadour, W., AiMohammadi, H., Almomany, A., \& Ahmed, A. (2020). Factors affecting the practice of incomesmoothing policy (an applied study on Sudanese banks). Journal of Entrepreneurship Education, 23(5), 1-22. Retrieved from https://www.abacademies.org/ articles/factors-affecting-the-practice-of-incomesmoothing-policy40an-applied-study-on-sudanesebanks41-9430.html

28. Schipper, K. (1989). Commentary on earnings management. Accounting Horizons, 3, 91-102.

29. Shah, A., \& Butt, S. (2011). Creative Accounting: A Tool to Help Companies in a Crisis or a Practice to Land Them into Crises. International Conference on Business and Economics Research, 16, 96-102. Retrieved from http://www.ipedr.com/vol16/18ICBER2011-A20010.pdf

30. Sparta, S., \& Trinova, N. (2020). The Effect of Income Smoothing and Procyclicality Behavior on the Bank Credit Impairment Losses with IAS 39 Adoption in PSAK 55 as a Moderating Variable. Journal of Economics, Business, \& Accountancy Ventura, 22(3). https://doi.org/10.14414/jebav. v22i3.1926

31. Takasu, Y. (2012). Does Income Smoothing Affect the Cost of Bank Loans? SSRN Electronic Journal. https://doi.org/10.2139/ ssrn. 2132070

32. Trisanti, T. (2014). Factors affected creative accounting practices in developing countries: A comparative study between Indonesian and Malaysia. JRAK, 10(1), 1-14. http://dx.doi. org/10.21460/jrak.2014.101.176

33. Warner, A., Goodwin, C., \& Amor, K. (2003). Uncovering Creative Accounting: A Practical Guide To The Judgement Areas Of Accounting. New York: Prentice Hall.

34. Yaseen, A. T., Idam, A. K., \& Fashakh, M. J. (2019). Creative Accounting Standards and its Techniques. Opción, 34(86), 1611-1642. Retrieved from https:// www.researchgate.net/publication/331687350_Creative_Accounting_Standards_and_its_ Techniques 